\title{
Teaching Video NeuroImages: Myoclonus as the presenting feature of Wilson disease
}

Niraj Kumar, MD, DM, and Deepak Kumar, MD

Neurology ${ }^{\circledR}$ 2019;92:e1667-e1668. doi:10.1212/WNL.0000000000007241

\author{
Correspondence \\ Dr. Kumar \\ drnirajkumarsingh@ \\ gmail.com
}

Figure Basal ganglia, thalamus, brainstem, and cortical involvement on MRI of the brain

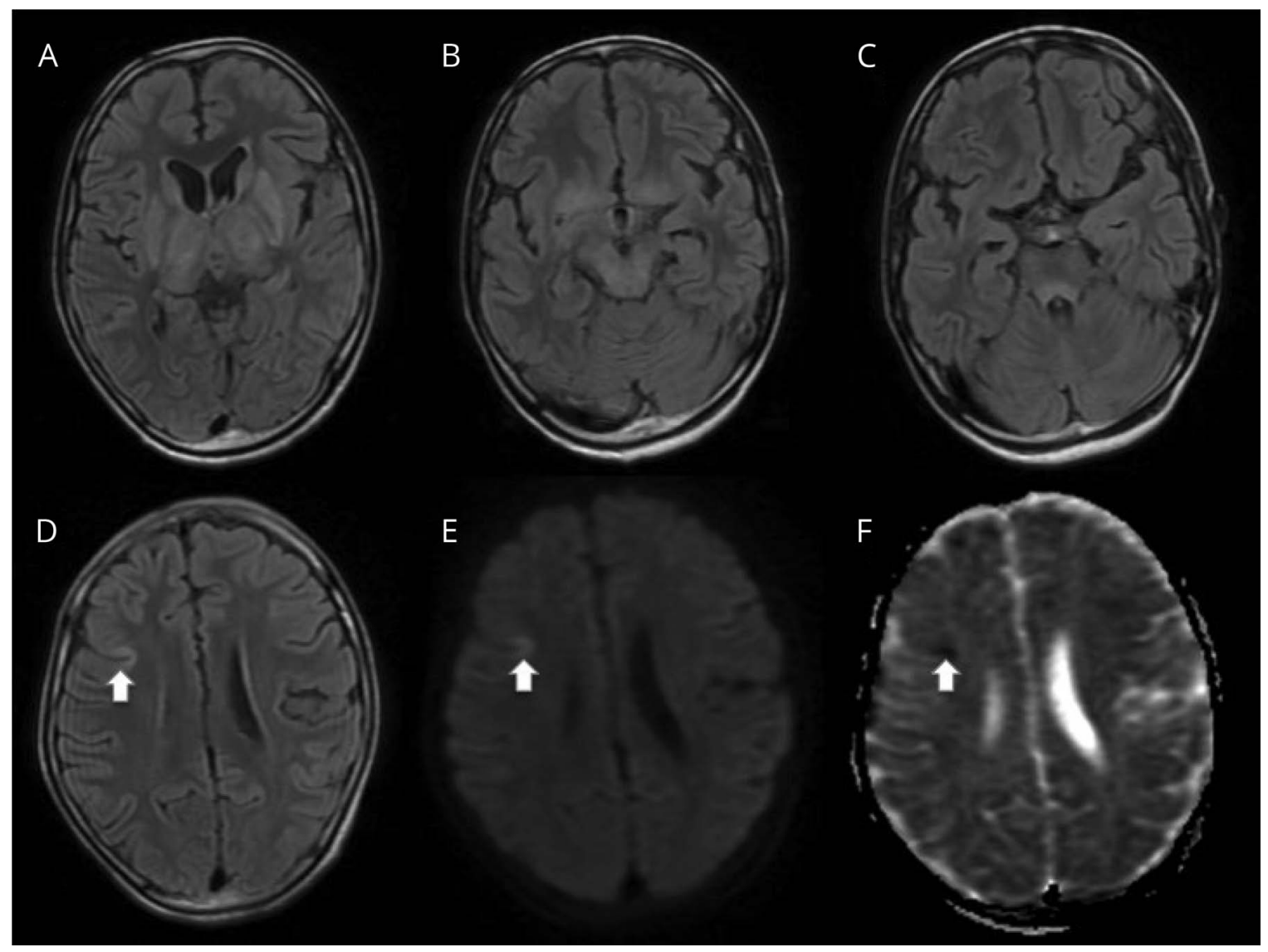

MRI of the brain shows fluid-attenuated inversion recovery hyperintensity in basal ganglia (A), thalami (A), midbrain (B), dorsal pons (C), and right frontal cortex (D, white arrow). Diffusion-weighted imaging ( $E$, white arrow) and apparent diffusion coefficient maps (F, white arrow) show a small area of diffusion restriction in the right frontal cortex.

A 10-year-old boy with no pertinent medical or family history developed repeated falls and progressive gait and speech decline over 1 year. Examination revealed multifocal myoclonus and generalized dystonia (video). EEG lacked epileptiform activity. Kayser-Fleischer rings, serum ceruloplasmin of $6 \mathrm{mg} / \mathrm{dL}$ (normal 20-60 mg/dL), and 24-hour urinary copper of $108.94 \mu \mathrm{g}$ (normal 15-60 $\mu \mathrm{g}$ ) confirmed Wilson disease (WD). MRI brain revealed T2 and fluid-attenuated inversion recovery hyperintensity in basal ganglia, thalami, brainstem, and right frontal cortex, with the latter showing diffusion restriction (figure). The patient improved
MORE ONLINE

\section{- Video}

$\rightarrow$ Teaching slides

links.lww.com/WNL/ A849

From the Departments of Neurology (N.K.) and Radiology (D.K.), Indira Gandhi Institute of Medical Sciences, Patna; and Department of Neurology (N.K.), All India Institute of Medical Sciences, Rishikesh, India.

Go to Neurology.org/N for full disclosures. Funding information and disclosures deemed relevant by the authors, if any, are provided at the end of the article. 
neurologically with zinc and penicillamine therapy. Myoclonus is uncommon in $\mathrm{WD},{ }^{1}$ with multifocal myoclonus at onset rarely reported. ${ }^{2}$

\section{Author contributions}

$\mathrm{N}$. Kumar: conception, design, and writing the first manuscript. D. Kumar: review and critique.

\section{Study funding}

No targeted funding reported.

\section{Disclosure}

The authors report no disclosures relevant to the manuscript. Go to Neurology.org/N for full disclosures.

\section{References}

1. Taly AB, Meenakshi-Sundaram S, Sinha S, Swamy HS, Arunodaya GR. Wilson disease. Medicine 2007;86:112-121.

2. Verma R, Holla V, Pandey S, Rizvi I. Multifocal myoclonus as a heralding manifestation of Wilson disease. J Pediatr Neurosci 2016;11:358-360. 


\section{Neurology}

Teaching Video NeuroImages: Myoclonus as the presenting feature of Wilson disease Niraj Kumar and Deepak Kumar

Neurology 2019;92;e1667-e1668

DOI 10.1212/WNL.0000000000007241

This information is current as of April 1, 2019

\section{Updated Information \&} Services

References

Permissions \& Licensing

Reprints including high resolution figures, can be found at: http://n.neurology.org/content/92/14/e1667.full

This article cites 2 articles, 0 of which you can access for free at: http://n.neurology.org/content/92/14/e1667.full\#ref-list-1

Information about reproducing this article in parts (figures,tables) or in its entirety can be found online at:

http://www.neurology.org/about/about_the_journal\#permissions

Information about ordering reprints can be found online:

http://n.neurology.org/subscribers/advertise

Neurology ${ }^{\circledR}$ is the official journal of the American Academy of Neurology. Published continuously since 1951, it is now a weekly with 48 issues per year. Copyright @ 2019 American Academy of Neurology. All rights reserved. Print ISSN: 0028-3878. Online ISSN: 1526-632X.

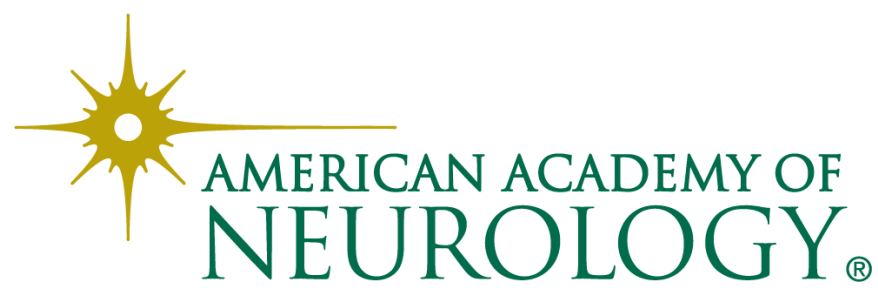

